\section{The Tonle Sap Lake, Cambodia: water-related conflicts with abundance of water}

\section{Marko Keskinen, Mira Käkönen, Prom Tola, and Olli Varis}

$\mathrm{T}$

he past decade has seen increasing discussion on water-related conflicts, water crises, and even water wars. ${ }^{1}$ This discussion has ranged from possible types of water-related conflicts to their scales, with a heated debate on whether conflicts will be more likely to occur within or between countries. There have also been arguments that water conflicts are not so much about water per se, but about the differences in values attached to water and related resources. ${ }^{2}$

In this article we analyze water-related tensions and conflicts within the Tonle Sap Lake area of Cambodia. We do so with three case studies that focus on different kinds of water uses. Revealing multiple dimensions and levels of water-related conflicts, they indicate that as a source of tension and conflict, prevailing power structures which include informal and formal arrangements of resource access and use - are far more important than the physical abundance of water itself.

Cambodia: a society in transition

Relatively rich in natural resources, ${ }^{3}$ Cambodia is one of the poorest countries in Asia when measured in monetary terms: its GNI per capita in 2005 was estimated to be a mere $\$ 380 .{ }^{4}$ The majority of its population is deeply dependent on common natural resources for their livelihood, with rice and fish forming the most important livelihood sources. Although the proportion of agriculture in GNI has been decreasing, over 70 percent of the labor force still works in the agricultural sector. ${ }^{5}$

Since the early 1990s, Cambodia has faced the challenges of multidimensional transition, shifting from long years of war to peace, from single-party politics toward democracy, and from command economy to market economy. ${ }^{6}$ It has opened up to regional and global economics and politics, and the entire Mekong region has moved toward closer cooperation, particularly in trade. Cambodian society has gone through significant political changes, and the pursuit of participatory democracy has left its mark. The results have often been mixed, and democratic processes currently overlap with different kinds of patronage structures. These dynamic changes have resulted in sociopolitical hybridization. ${ }^{7}$

While Cambodia's economic growth has been relatively rapid, development has been far from equal and the disparities keep growing particularly between urban and rural areas. ${ }^{8}$ Among the main challenges for equal development are weak and nontransparent governance; these also contribute to polarization of the society. ${ }^{9}$ Political dominance of the ruling party and coalescence of bureaucratic, economic, and military power have influenced natural resources management as, e.g., fish and forest resources offer an easy income source for the well-connected elite. ${ }^{10}$ Indeed, as noted by the World Bank, many of Cambodia's development challenges are "fundamentally about 'governance,' that is, how the rules, institutions, and systems of the state operate and how the state relates to citizens, civil society and the private sector in terms of transparency and accountability." 11

Cambodia's formal governance system suffers from horizontal discontinuities. For example, water-related issues are handled under several ministries with different mandates, ambitions, and policies. Also troublesome are the functioning of vertical links among central government, provincial and local authorities, and villages. Consequently, on-going decentralization programs - including initiatives for community-based natural resource management - aim at strengthening local level governance, facilitating bottom-up processes and improving the two-way flow of information along vertical links. An additional twist in Cambodia's governance system is its aid dependency and the relative dominance of donors and international NGOs in shaping government policies and introducing new approaches such as decentralization and participation. ${ }^{12}$

Tonle Sap Lake: a natural and hydrological wonder

The Tonle Sap Lake (Figure 1) and its resources form a central source of livelihoods and food for well over one million people living in the lake are and its flood plains. ${ }^{13}$ However, Tonle Sap's significance extends much further as it is estimated that half of Cambodia's population benefits directly or indirectly from the lake's resources. ${ }^{14}$ Despite the relative richness of the area's natural resources and its abundance of water, the Tonle Sap area remains one of Cambodia's poorest when measured in monetary terms.

The Tonle Sap Lake is known for its extraordinary flood pulse system with a remarkable but nevertheless regular seasonal variation in the lake's water volume and level. ${ }^{15}$ During the rainy season part of the Mekong's floodwaters flow to the lake, and the lake's surface area quadruples. An exceptional and highly productive flood plain ecosystem has been formed: the Tonle Sap is believed to be among the world's most productive freshwater ecosystems. ${ }^{16}$

\section{Water-related conflicts in the Tonle Sap}

The case studies in this article describe conflicts in the Tonle Sap area related to flood plains, agricultural land, and fisheries. These resources are in different ways enabled, supported, and nurtured by water.

While the case studies focus on different aspects and dimensions of water-related conflict, all of them are essentially about the inequality in access to and control over natural resources and thus about different kinds of power structures. One way of 
viewing the different interests, power relations, and inequalities in resource allocation is to look at them through the concept of structural violence. It implies that violence can be built into the structures of a society, resulting in unequal life chances. ${ }^{17} \mathrm{By}$ discussing the mechanisms that marginalize the poor and deny them rights to use natural resources to meet their subsistence needs, the case studies in this article address important aspects of structural violence in relation to natural resource management. ${ }^{18}$

Local, largely subsistence-based livelihood activities directly based on natural resources are often the ones that degrade most with "development."19 Related governance challenges can thus be seen to reflect prevailing conceptualizations of development and the consequent valuation of water and related resources. This comes close to the discussion on symbolic violence that some see as an important dimension in conflicts over natural resource use. ${ }^{20}$ For example, most state-level actors seem to value modernist schemes such as large-scale irrigation and hydropower dam construction more than traditional livelihoods. Also justifications for intervention e.g., in form of impact assessments - are often done by scientists and even the very language they use excludes local communities from discussions that concerns their future lives.

Case 1: Upstream development threatening flood plain ecosystem and livelihoods

This section is a case study about possible effects that upstream development in other Mekong basin nations is likely to have on the ecosystem and livelihoods of the Tonle Sap flood plain. ${ }^{21}$ The case addresses the issue of different scales of water-related conflict and bridges the discussion between intra- and interstate conflict. The section reviews regional cooperation mechanisms and discusses why transboundary impacts - despite their negative effects and consequent tensions between the countries - are unlikely to escalate to interstate conflict.

\section{Transboundary impacts on the Tonle Sap flood plain}

The flood plains surrounding the Tonle Sap support local people in many ways; a large variety of flood plain products provide food, traditional medicine, firewood and income for villagers, and flooded forests provide shelter for floating villages during the floods. Flooded forests and shrubs also form a key element of Tonle Sap's ecosystem and play a critical role in sustaining its aquatic production. ${ }^{22}$ However, the area of the flooded forest has been shrinking rapidly, e.g., due to firewood cutting and of conversion of the flooded forests into agricultural land. ${ }^{23}$

Recent cumulative impact assessment studies indicate that a planned development in the upstream parts of the Mekong River and its tributaries - most notably the construction of large hydropower dams in China and Laos - are likely to cause an increase in the dry-season water level in the lower parts of the Mekong, and

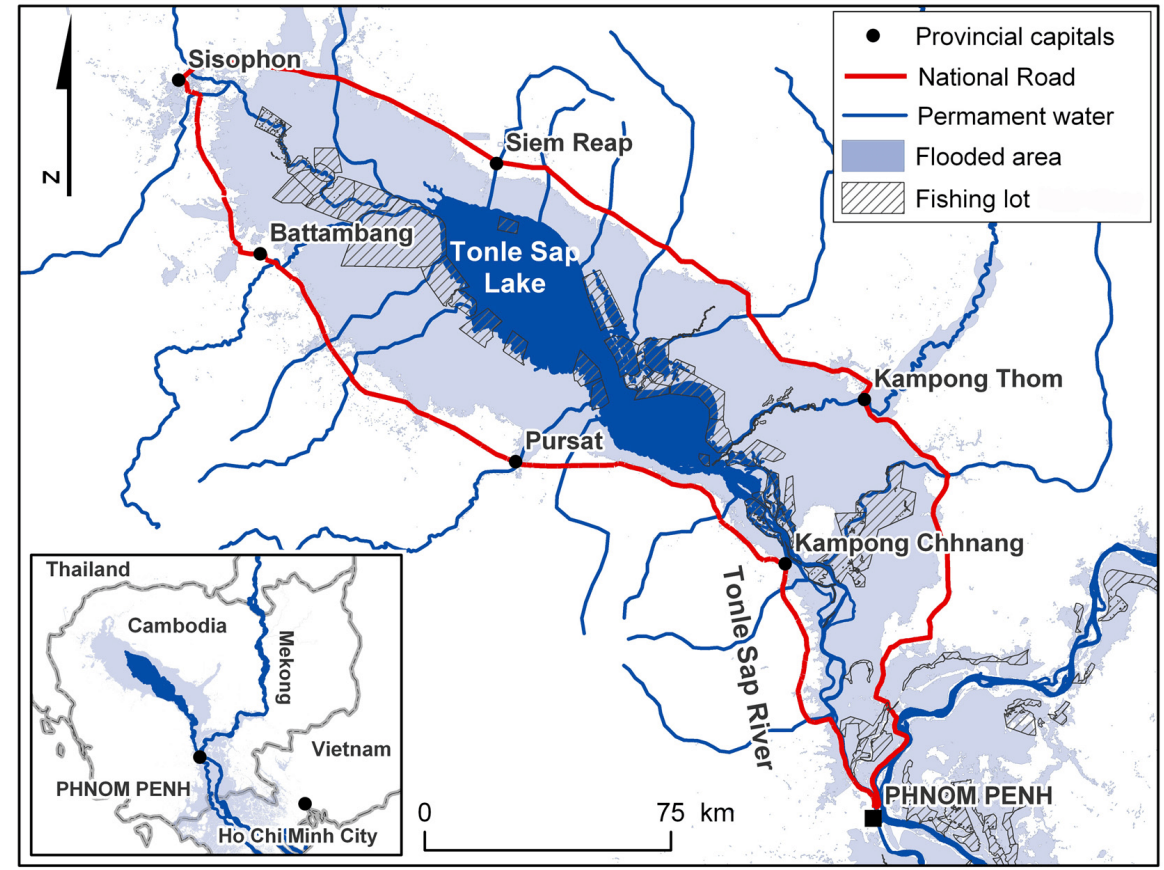

Figure 1: Tonle Sap Lake and floodplains, together with private fishing lot areas. Map by Matti Kummu.

consequently in the Tonle Sap Lake. ${ }^{24}$ The rise of dry-season water level means an extension of the permanent lake area and thus changes in the flood plain. The most notable change would be permanent submersion, in essence destruction, of remarkable areas of remaining flooded forests surrounding the lake. ${ }^{25}$

The reduction of flooded forest area would mean loss of livelihood sources for a significant number of people, both due to loss of flooded forests per se and due to consequent negative effects on aquatic production. ${ }^{26}$ These are also likely to result in increased pressure on other natural resources as more people would rely on fewer remaining resources. Thus, increased water development in other Mekong countries would cause negative effects for the ecosystem and livelihoods of the Tonle Sap flood plain and potentially fuel additional water- and resource-related conflict in the area.

Local impacts not visible in regional discussion

When considering possible transboundary impacts on Tonle Sap, it is important to note that there exist regional cooperation organizations in the Mekong basin that aim to facilitate discussion between riparian countries about impacts and trade-offs of 
water development. The best-known organizations are the Mekong River Commission and the Greater Mekong Subregion (GMS) Program. ${ }^{27}$ But despite these regional cooperation mechanisms and despite an increasing number of studies indicating adverse transboundary effects, Cambodia's government seems not to be eager to bring them up - at least not publicly. ${ }^{28}$

One of the main reasons for this appears to lie in increasing regional economic cooperation, particularly China's growing economic cooperation and assistance for Cambodia. Apparently, the Cambodian government does not wish to risk its regional economic cooperation by getting into difficult dialogue about possible transboundary impacts with upstream countries. This stance has clearly strengthened over the past few years, ${ }^{29}$ concurrent to a remarkable increase in China's economic and technical cooperation with Cambodia, for example in hydropower construction. ${ }^{30}$

While adverse transboundary impacts among riparian states can result in water-related intrastate tensions, locallevel adverse effects are not necessarily considered in interstate discussions.
This finding supports the view that riparian countries prefer to cooperate economically rather than to get into substantial conflict over water. ${ }^{31}$ At the same time, however, the case also raises an important point in the discussion of interstate and intrastate water conflicts. While it indeed seems possible that transboundary impacts between riparian countries can result in increased water-related tensions within a country, the local level negative impacts are not necessarily considered in the regional discussions between riparian countries' governments.

\section{Case 2: Appropriation of agricultural land in the flood plain}

Improving agricultural productivity is seen as crucial for Cambodia's economic growth. ${ }^{32}$ This has its implications for the Tonle Sap area as well. Rapid agricultural development, including large-scale irrigation projects, is taking place in the upper parts of the basin. Many of these projects are managed by governmental line agencies and supported for instance by the Asian Development Bank. Also private initiatives for agricultural development are occurring, but they are taking place mainly in Tonle Sap's flood plains. These new phenomena influence the availability of resources to different user groups.

The Tonle Sap flood plains differ in many aspects from the surrounding uplands. Traditionally, large parts of the flood plains - particularly those close to the lake that are submerged for longer periods of time - have not been under clear ownership or cultivation, but have been used for various purposes. ${ }^{33}$ Many are so-called communal areas, their use being based on customary user rights without efficient control or "domestication" by government. The drive for agricultural production along with improved accessibility of the Tonle Sap area ${ }^{34}$ and increased land value has led private investors - often belonging to the country's elite with connections to investors elsewhere in Southeast Asia - to see the flood plain areas as profitable targets for investment. This has brought its own challenges and increased tensions in the area.

\section{Emerging private irrigation areas in the flood plains}

The increased flow of investments to Tonle Sap's flood plains has materialized in the form of a rapid expansion of irrigated agriculture and related structures such as large embankments and reservoirs. These are intended primarily for profitable dry-season rice cultivation. ${ }^{35}$ Concessions for these private initiatives are usually granted by provincial or central government, but the granting procedures seem often dubious and many - including government officials - claim that a significant proportion of new irrigation areas and structures are in fact illegal. ${ }^{36}$

The emergence of private irrigation areas in the Tonle Sap flood plain has meant that many local communes have lost areas that they have traditionally used, e.g., for floating rice cultivation and as grazing grounds for cattle, thus undermining local customary rights. As these areas are usually not officially titled to villagers, the villagers have weak possibilities to influence the construction of new structures and have not even been able to get proper compensation for their losses. Moreover, our field surveys indicate that private concessionaires plan to charge local farmers for irrigation water from their reservoirs, and this has caused additional tensions. ${ }^{37}$

Private irrigation areas have also faced resistance. Some of the planned irrigation development projects in different parts of the flood plain have been halted due to increased pressure from local people and NGOs. ${ }^{38}$ In addition, some provincial agencies have brought up problems related to the new irrigation projects, including their possible negative impacts on fisheries as well as on local livelihoods. ${ }^{39}$ Thus, even though the emerging development is basically supported by central and provincial governments, and concession rights were guaranteed by government officials, these officials are not unanimous about the legitimacy of the land appropriation process.

These differing views of government officials are related to the line agencies' confusion about whom the responsibility for the management and development of the flood plain areas actually belongs to. ${ }^{40}$ The confusion is linked with existing institutional rivalries between different ministries over the responsibility - and resources - for agricultural development. ${ }^{41}$ Different line agencies also see the possible impacts of the private irrigation development differently: as none of the private irrigation structures include a proper impact assessment process, the irrigation structures' impacts, e.g., to the fisheries has therefore not been appropriately assessed.

The conflict over the use and control of flood plain areas is thus closely linked with the broader governance context and its ambiguities. The roots for the conflict can also be seen in the vagueness of the ownership of flood plain land areas that have traditionally been under community user rights but are now differently recognized by 
different parties.

\section{Case 3: Practices of exclusion in Tonle Sap fisheries}

Fish forms the main source of income and food particularly to the poorest and most vulnerable groups of people in Cambodia. ${ }^{42}$ Well-functioning and equal fisheries management would therefore be crucial for balanced development of the country Unfortunately this is not the case. Cambodia's fisheries management - like the management of many of its other resources - is dominated by weak implementation of policies, lack of accountability, and non-transparent and unjust practices. ${ }^{43}$ Accordingly, different kinds of conflicts related to fishing and particularly to access to and control over different fishing areas exist, two of which are presented in this section. $^{44}$

Conflicts with private fishing lots

Cambodia's fisheries management is marked by appropriations and exclusions from access of the local communities. The epitome of this is the operation of large-scale, commercial fisheries that is based on so-called fishing lot system. Fishing lots are geographical concessions auctioned to the highest bidder for a certain period, usually two years. The lots include lake areas, rivers, ponds, and inundated forest and are typically located in the most productive fishing areas. The owner of the fishing lot has an exclusive right to harvest fish from the lot, to sublease parts of the lots, and to keep everyone else out from the lot area. ${ }^{45}$

The fishing lots are allowed to operate only during the most important fishing season which, in theory, leaves lots accessible for small-scale subsistence fishing for the rest of the year. But many lot owners limit the access to lots throughout the year, and some lots have also extended their areas to community fishing areas, open access areas, and fish conservation zones, creating thus both geographical and temporal conflicts over access to fishing areas. In short, the system excludes most people from the most productive fishing areas during the most productive fishing season. ${ }^{46}$

It is therefore no surprise that the fishing lot system has created serious tensions and even armed conflict between local villagers and fishing lot owners and their guards. Tensions were soaring at the turn of the millennium, when villagers around the Tonle Sap started to protest more loudly against the exclusionary fishing lot system, the extended boundaries of lot areas, and government's inability to respond to the conflict. ${ }^{47}$ Responding to the accumulation of fisheries conflict, the government proclaimed in 2001 radical and sudden changes to the country's fisheries management. Half of the total area of the private fishing lots was changed to public fishing lots open for community fisheries. This shift aimed to improve peoples' food security and to ease the growing tensions between local people and fishing lot owners.
Conflicting interests in community fisheries

The fisheries reform of 2001 experienced certain setbacks and some believe that the tensions just took different forms. ${ }^{48}$ Although the release of more areas for community fishing was overall a

positive shift and eased tensions between fishers and fishing lot owners, management of community fishing areas has turned out to be challenging. ${ }^{49}$ Among the main reasons for these challenges is that the institutional arrangements of community fisheries seem often to ignore the heterogeneity of local communities and the complexity of local power structures. ${ }^{50}$

The underlying assumptions for the common ethos of community-based fisheries management are often unrealistic; they assume that all local fishers - including larger scale fishers - would easily become environmental "shepherds" and agree to limit their activities to subsistence levels. This points toward government's and donors' lack of sensitivity to resource users' own perceptions on their resource use as well as to the fact that fishing communities consist of fishers with different scales of activities. An additional challenge for community management is that fish are commonly seen as a commodity by the fishers, not least because of the long moral influence of the private lot system. Tonle Sap is thus rather special in that the development of new institutional arrangements does not originate from the "tragedy of open access," but rather from the "tragedy of privatization."

At the same time, the continued operation of private fishing $\operatorname{lots}^{51}$ seriously undermines the legitimacy of regulatory measures in community fishing areas and discourages compliance with law. Findings from our field surveys indicate that many villagers saw the community fisheries' regulations that restrict villagers' fishing to subsistence levels hard to justify when compared to the liberties given to private fishing lot owners. This relates to broader questions about the context of and values behind current fisheries governance: who has the right to consider fish a commodity and who is to be restricted to subsistence fishing, and do local fishers have rights to defend their livelihood or just rights to defend subsistence fishing that they are by law restricted to?

Another emerging difficulty in the community fisheries is so-called elite capture. There naturally exist various power relations and interests within a fishing community that are then combined with outside interests. As a result, those with a strong asset base and high social and political capital dominate easily the agenda and activities of the community fisheries. Indeed, findings from our field surveys indicate that many of the current community fisheries management systems in the areas with high prior heterogeneity among the local fishers have failed to take the local power structures 
The drive toward greater participation leaves space for silent conflicts, as communicative ideals of participation fail to address the "dark side" of power and politicking within planning institutions, planning practice, communication, and social relations. Silent conflict thus potentially results in continuities of local repressive structures. properly into account, and are actually maintaining existing local power imbalances.

The wealthier groups in our survey villages were significantly more represented in the management of community fisheries, capturing the best fishing grounds, and at the same time restricting the access of poorer groups - even when official rules and regulations aim to reduce these kinds of exclusive practices. The situation is thus paradoxical: an institutional arrangement designed for subsistence fishers has turned into one that excludes them, and instead provides a negotiation ground for medium or larger-scale fishers as well as a means to control the activities of the poorer ones.

The lack of cultural sensitivity of donor-driven reforms can be seen as one issue explaining this paradox. While decentralized natural resource management aims at more equal allocation of benefits from natural resources, democratic communicative practices might not always reduce local power imbalances, although they might take new forms. Southeast Asian world views are often considered to favor harmony over open discussion that could bring up conflict-prone topics. Although this is naturally a simplification, it has discovered that the drive toward greater participation indeed leaves space for so-called silent conflicts, as communicative ideals of participation fail to address the "dark side" of power and politicking within planning institutions, planning practice, communication, and social relations. ${ }^{52}$ Silent conflict thus potentially results in continuities of local repressive structures. ${ }^{53}$

Discussion: the different dimensions of water-related conflicts

We analyzed characteristics of water-related conflicts in three case studies from Cambodia's Tonle Sap Lake focusing on flood plains, agricultural land, and fisheries. The cases encompass different dimensions and aspects of water-related conflicts.

The case study on fisheries (case 3 ) focused on conflicts between fishers and on the role of fisheries management in those conflicts. Until the fisheries reform of 2001 , Cambodia's fisheries management was structurally violent toward local fishers in that private fishing lots excluded local communities from most of the major fishing areas. Although these excluding practices still exist, the situation has improved and many of the fishing areas have been shifted to fall under local community management. Consequently, one interesting finding from the fisheries case is that conflicts should not be seen only in a negative light, but may also be seen as a driver for change. As the fisheries reform showed, the accumulating resistance of local fishing communities that conflicted openly with private fishing concessions was the driver for development of more equal laws, rules, and regulations in fisheries management, thus reducing potential future conflicts. Conflict may thus play a constructive role in facilitating social and economic transformation as well as in shaping social relations and power structures. $^{54}$

Fisheries reform, however, did not come without challenges. One difficulty in this otherwise positive reform was that it was done in a hasty manner without sufficient commitment from state actors and proper involvement of the local level. In addition, the reform was greatly influenced by the donor community. A danger with initiatives driven by the donor community is that the general policies they imply are often rather detached from local reality and therefore likely to cause unintended and undesirable results. ${ }^{55}$ As demonstrated by the fisheries case, if new institutional and participatory arrangements are designed without proper understanding of local realities and sociopolitical structures, they are - despite their good intentions - likely to result in participatory processes that merely reproduce dominant power structures.

The case study on land appropriations in the flood plains (case 2) revealed a situation where traditional use of a resource is being undermined by powerful groups The combination of increased accessibility to the flood plains and unclear legal status of the flood plains areas have left these areas exposed to uncontrolled privatization and resulted in conflicts between local communes and outside appropriators and private investors. The case revealed that formal rules and regulations do not properly recognize local communities' customary user rights - that have existed as practical norms for generations - to utilize agricultural land.

Comparison of these two cases reveals an interesting difference: whereas the flood plains areas are increasingly being transformed from common to private areas, the fishing domains are being reconverted from private concessions to community user groups. Different water-related resources have different histories and are perceived differently by local users. Consequently, without sensitivity to the resource users' own perceptions on their resource use, attempts to understand tensions related to resource use are likely to fail. Local communities are not homogenous entities; they entail different user groups with differing perceptions on the resources they use.

While the cases on fisheries and agricultural land focused on conflicts within the Tonle Sap area, case 1 elaborated on possible adverse transboundary impacts from upstream Mekong countries. The case also addressed the diverse conceptualizations of development and differing values attached to natural resources by actors in different levels and scales. The discussion on why water-related conflicts are unlikely to scale up to the regional level indicated that national decisionmakers seem not to be aware of - or are even ignorant toward - concerns about transboundary impacts at the local level. The political elites, irrespective of their country, seem to have similar modernization aspirations and common economic interests, and they are thus more likely to find consensus than to end up in serious conflict over water development in 
the basin. Discussion about interstate water conflict is thus not likely to be meaningful in the Mekong basin. However, this conclusion shows only one side of the coin as at the same time the seemingly fluent regional cooperation seems to prevent actual discussion about negative transboundary impacts at the local level.

This finding relates to James C. Scott's idea on state simplifications. ${ }^{56}$ The tradeoffs between livelihood sources look different when viewed from the state rather than the local level. Calculations based on abstract forms of knowledge and information render livelihood issues of farmers and fishers living around the Tonle Sap into estimations of general productivity and profitability, ignoring political and moral dimensions of the trade-offs. The trade-offs are usually made on issues that many locals could not consider calculable or comparable. Thus, a common characteristic for all three cases is found to be related to unequal power structures and mechanisms of marginalization within and between the different scales.

Conclusion: the importance of the governance context

The three case studies indicate how diverse and multidimensional water-related tensions and conflicts are in the context of the Tonle Sap. It becomes obvious that water-related conflicts are rarely solely about water and its scarcity (or abundance), but that access to and control over water and related resources are actually often more dominant reasons for water-related conflicts.

W ater-related conflicts cannot thus be linked to increased resource scarcity alone but also - and perhaps mainly - to unequal distribution of water and related resources. Consequently, we see that the discussion on water conflicts should focus much more on the mechanisms of allocation of water and related resources as well as on formal and informal power structures shaping these mechanisms. In addition, different valuations attached to the resources as well as the political and historical context where they prevail have a strong influence on tensions over resource use. Consequently, water-related conflicts should always be examined in a broader context, with special attention to existing power structures both at local and highernational and regional - levels. These findings reinforce many other studies on conflict and natural resources. ${ }^{57}$

\section{Notes}

Marko Keskinen is a researcher and Ph.D. candidate at the Water Resources Laboratory of Helsinki University of Technology, Finland. His research focuses on the interactions between water and society as well as on multi- and cross-disciplinary approaches of water management. He may be reached at keskinen@iki.fi. Mira

Käkönen is a master's degree student at the Department of Sociology in the University of Helsinki with experience in natural resource management-related projects in the Mekong region. Her research interests are in power and knowledge relations and changes in expertise in environment and development issues. Prom Tola is an independent researcher and consultant from Phnom Penh, Cambodia. He has long experience in natural resource management and participatory approaches. Olli Varis

is a senior researcher at the Water Resources Laboratory of Helsinki University of Technology and has broad, interdisciplinary experiences on water, environment, and development research and consultation. He is a frequently used expert by various U.N. and other international organizations and is the author of over 300 scientific papers. We are grateful for comments and support provided by numerous colleagues and fellow researchers in the Mekong region. Special thanks are due to Matti Kummu, Juha Sarkkula, Jorma Koponen, and Professor Pertti Vakkilainen as well as to our Cambodian colleagues Yim Sambo and Suong Leakhena who were instrumental in facilitating the field surveys. For fluent collaboration and inspiring discussions we also thank Mak Sithirith, Dil Bahadur Rahut, Blake Ratner, and Babette Resurreccion.

1. See, e.g., Ohlsson (1999); Haftendorn (2000); Postel and Wolf(2001); Watkins and Berntell (2006).

2. For instance, Shiva (2002).

3. It has been suggested that Cambodia has one of the highest natural resource availability per capita in Asia (Kurien, et al., 2006; World Bank, 2004), but there seems not to be a proper study on this.

\section{World Bank (2006a)}

5. This decline is partly due to natural disasters, i.e., drought and high floods during the past few years. See NIS (2004). In these statistics the agricultural sector includes also fishing and forestry.

6. Le Billon (2007).

7. Öjendal and Sedara (2006). It is important to note that the sociopolitical structures usually considered as obstacles for democracy, such as patron-client relations and authoritarianism, are not as static as is often thought. 
8. Although the estimated poverty incidence in Cambodia fell from 47 percent to 35 percent from 1994 to 2004, per capita consumption among the poorest fifth of the population rose by only 8 percent, compared to 45 percent among the richest fifth. The Gini coefficient (measuring inequality in the income distribution) grew from 0.35 in 1994 to 0.40 in 2004. Poverty sunk much faster in urban than in rural areas, and the inequalities grew particularly in rural areas (World Bank, 2006b).

9. World Bank (2004, 2006a).

10. Le Billon (2000, 2007); Tarr (2003).

11. World Bank (2006b, p. 131).

12. There naturally are a variety of practical norms when implementing these policies. For example, decentralization and its importance might be differently interpreted by different groups. The on-going decentralization process would probably not have taken place if it had not been interpreted by the ruling party as a new source of means to gain popularity and legitimacy. Thus decentralization has actually not been "participatory revolution," but merely "power politics as usual" (Öjendal and Sedara, 2006).

13. Keskinen (2006).

14. Bonheur (2001).

15. Lamberts (2006).

16. However, as noted by Lamberts (2006), there is currently very little information available on the actual ecosystem productivity of the Tonle Sap, and the available data is particularly ambiguous on fisheries.

17. See Galtung (1969); Farmer (1997). According to Galtung (1969, p. 168), structural violence refers to the mechanisms of exclusion and inequality and poverty that constrain the physical and mental capacities of the poor and denies them a decent life. Galtung sees violence consisting of factors that "cause people's actual physical and mental realizations to be below their potential realizations."

18. Exclusory mechanisms are partly based on ethnicity; in particular, Cambodia's Vietnamese minority is regularly deprived of basic rights such as land ownership. They are also often excluded from official statistics and enumerations, and it is therefore impossible to give their exact number. However, they are particularly numerous in the floating villages of the Tonle Sap, and it has been estimated that at least 14 percent of the population (around 12,000 people) in those villages would be ethnic Vietnamese (Keskinen, 2003)

19. Bryant and Bailey (1997).

20. For example, Peluso and Watts (2001)

21. In addition to the potential transboundary impacts discussed in this section, other kinds of transboundary impacts occur in the Mekong basin. For instance, Cambodia has suffered from Vietnam's water development in different ways. The Vietnamese flood protection structures along the Cambodian border (built to reduce flood damages on the Vietnamese side) have resulted in increased flooding in Cambodia (Bown, 2003). Also, the Mekong's tributaries in the Vietnamese Central Highlands have been a site for increased irrigation abstractions, deforestation, and dam construction that have had adverse effects on the Cambodian side. Perhaps the best-known case is the construction of Yali Falls Dam that has caused loss of river-bank agricultural areas, increased erosion, and losses for fisheries on the Cambodian side of the Se San River (Baird and Mean, 2005).

\section{Kummu, et al. (2007); Evans, et al. (2004).}

23. Evans, et al. (2004) estimate that between 1973 and 1997 the flooded forest cover in the Tonle Sap area has reduced over 50 percent. See Evans, et al. (2004); Degen, et al. (2000). The conversion of flooded forests into agricultural land has also induced conflicts between farmers and fishers. While fishers (including fishing lot owners) want to preserve the flooded forest to sustain Tonle Sap's high fish production, farmers - some of whom seem to be shifting from fishing to farming due to reduced fish catch - want to convert the forest areas to agricultural land.

\section{Kummu, et al. (2007).}

25. Kummu (2007) estimates that a $30 \mathrm{~cm}$ increase in Tonle Sap's dry-season water level would permanently submerge up to one third of the remaining flooded forest area.

26. Although the Tonle Sap area's population is concentrated on the upper fringes of the flood plain, an estimated over 140,000 people live in the actual flood plains, i.e., in the area that is submerged practically every year (area between $0 \mathrm{~m}$ and $8 \mathrm{~m}$ above sea level). See Keskinen (2006). 
27. The Mekong River Commission (MRC) focuses on water management, but only four of the six downstream countries are members (Laos, Thailand, Cambodia, and Vietnam; but not China and Burma/Myanmar). The GMS Program has all six Mekong countries as it members and it focuses on economic and infrastructure development, but some environmental and water issues are also on its agenda.

28. Despite the MRC's commonly agreed rules of equitable utilization of the Mekong's waters, local livelihoods are still in various ways threatened by water development in the basin. This paradox can be understood partly through the statecenterd structure of the regional organizations. As noted by Fox and Sneddon (2004) for example, the MRC as an inter-governmental organization seems to dismiss that the river is a host of complex socioecological dynamics, and instead sees it simplistically as a watercourse where water is allocated in equal quantities among the countries.

29. In 2003 Cambodian prime minister Hun Sen said in a speech that "... the upstream countries' projects in the Mekong River, namely the continued dam constructions and commercial navigation plan, have become a major concern for the downstream countries including Cambodia," and he was particularly concerned about the negative impacts to the Tonle Sap (Cambodia New Vision, 2003). Two years later, just before heading to the Second GMS Summit in China, Hun Sen was quoted saying that he believes hydropower dams built by upstream countries will pose "no problems" to Cambodia, and he criticized that people who are claiming otherwise just want to undermine the unity among the riparian countries (People's Daily Online, 2005). At the same time China's economic assistance to Cambodia has increased remarkably (Keskinen, et al., 2007).

30. Keskinen, et al. (2007).

31. See, e.g., Pryor (2007).

32. World Bank (2006b).

33. Land title remains unclear in most areas of Cambodia

34. National roads surrounding the flood plains as well as many smaller rural roads have during the past years been improved remarkably.

35. For example, Evans, et al. (2005) note that at least 15-20 dams/embankments for dry-season rice cultivation have been built in the $91.5 \mathrm{~km}^{2}$ study area in Kampong Thom since 2003. These structures capture receding flood waters, are long (typically extending 0.5-2 km), and can each irrigate hundreds of hectares.
36. For example, in Kampong Thom province, an interviewed provincial officer estimated that up to half of the private irrigation areas in the province would be illegally built.

37. Field surveys were carried out in fall 2006 by Mira Käkönen, together with Yim Sambo, Suong Leakhena, and Marko Keskinen, in three different locations around the Tonle Sap Lake, adjacent to the surveys of the so-called Built Structures Project

38. Findings from our field surveys indicate that, e.g., in Battambang province the development of approximately 6,450 hectares of land bought/leased by CityMart company is at a standstill due the strong opposition of local farmers and NGOs who criticize that the project acquired the land areas illegally.

39. Our field surveys indicate that, e.g., in Kampong Thom the provincial departments of agriculture and fishery are addressing the problems related to private irrigation structures and are demanding removal of some of the new structures.

40. The ministries involved include, e.g., the Ministry of Water Resources and Meteorology and the Ministry of Agriculture, Forestry, and Fisheries. While the latter seems to prefer more diversified and smaller-scale agricultural development, the former is keener to plan and build large-scale irrigation schemes and has been more active in promoting private land concession around the lake.

41. As pointed out by Ratner, et al. (2004), the confusion and even institutional rivalries over the formal division of authority in natural resource management is quite common in the case of wetlands due to its ambiguous nature.

42. Sithirith and Grundy-Warr (2007); Navy, et al. (2006); McKenney and Tola (2002).

43. Ratner (2006); Salayo, et al. (2006).

44. Salayo, et al. (2006) and Sithirith and Grundy-Warr (2007) recognize five different kinds of fishing-related conflicts in Tonle Sap, including, e.g., those between fishers and other users of aquatic resources (e.g., lowland farmers) as well as with "outsiders" migrating seasonally to the lake and its flood plain to fish. We focus here only on conflict among fishers and also leave out ethnic aspects (particularly with ethnic Vietnamese) that include some serious tensions as well.

45. Actually a lessee, but the term "lot owner" is much more commonly used, reflecting the dominance of the lessee over the fishing lot area. 
46. In addition, there have been conflicts between fishing lot owners and farmers over water use rights, related mainly to diverting and storing flood waters, and consequently fish (Degen, et al., 2000).

47. For more information on this topic, see, e.g., Resurreccion (2006); Sina (2003); Bonheur (2002); NGO Forum (2000); Degen, et al. (2000).

48. McKenney and Tola (2002); Bonheur (2002); Ratner (2006).

49. However, only a part of the released fishing lots is currently under community management, with the rest being so-called open access fishing areas (McKenney and Tola, 2002). As noted by Degen, et al. (2000), the notion of open access is erroneous as a majority of these areas are actually under informal ownership and management arrangements, often imposed by lot owners and powerful local elite and excluding the poorer subsistence fishers. It would thus be perhaps better to refer, e.g., to the concept of common pool resources instead of open access resources (cf., Ostrom, 1990).

50. For innovative analysis on formal and informal power structures in Tonle Sap's community fisheries, and particularly on the challenges of women's participation in it, see Resurreccion (2006).

51. Even after fisheries reform, half of the private fishing lots continue their operation and apply significantly larger scale - and often illegal - fishing methods compared to the methods allowed for subsistence fishing. In the Tonle Sap Area 53.4 percent of the lot areas prior to 2001 are still under private fishing lot system. In Battambang and Kampong Chnang provinces - where many of the most productive fishing areas are located - this figure is over 70 percent (McKenney and Tola, 2002). Consequently, an additional disincentive for participation in community fisheries is that the fisheries' production in several new community fishing areas is fairly low.

\section{Tam (2006).}

53. This conclusion should not be interpreted simply as a lack of capacity for collective action in Cambodian communities. Spontaneous local activities and initiatives challenging authoritarian structures have followed from decentralization in Cambodia, also in the management of natural resources (Middleton and Tola, 2007). The challenge is that the community fisheries reform was initiated in a top-down manner and the responsibility does not therefore actually lie at the local level. The new local community fisheries can work meaningfully only if they are truly supported by a broader governance context that values equitable resource allocation. Fishers in our surveys often expressed frustration with the lack of attention and support from higher level authorities and with the reluctance of authorities to properly control private lots as well as the actions of local fisher elites in community fishing areas.

$$
\text { 54. Cf. Upreti (2001). }
$$

55. More general discussion on current water policies in the Mekong region and their mismatches with local realities can be found, e.g., in Molle (2005).

56. Scott (1998).

57. See, e.g., Bryant and Bailey (1997); Peluso and Watts (2001); Upreti (2001).

\section{References}

Baird, I.G. and M. Mean. 2005. "Sesan River Fisheries Monitoring in Ratanakiri Province, Northeast Cambodia: Before and After the Construction of the Yali Falls Dam in the Central Highlands of Viet Nam." 3S Rivers Protection Network, in cooperation with the Global Association for People and the Environment, Ratanakiri, Cambodia.

Bonheur, N. 2002. "National Report on the Prevention and Resolution of Environmental Conflicts in the Mekong River Basin - Cambodia." A Report prepared for CNMC and MRC.

Bonheur, N. 2001 "Tonle Sap Ecosystem and Value." Technical Coordination Unit for Tonle Sap, Ministry of Environment, Phnom Penh.

Bown, S. 2003. "The Effect of Flooding on Livelihoods of Cambodians Living Nea the 'Vietnam Dam'." A Report Prepared for Chamroeun Cheit Khmer, Takeo and Oxfam GB, Phnom Penh.

Bryant, L.R. and S. Bailey. 1997. Third World Political Ecology. London: Routledge. Cambodia New Vision. 2003. "Addressing the Management of Large Rivers Symposium." Speech by Prime Minister Hun Sen, Issue 61, the Cabinet of Samdech Hun Sen.

Degen, P., F. van Acker, N. van Zalinge, N. Thuok, and L. Vuthy. 2000. "Taken for Granted - Conflicts over Cambodia's Freshwater Fish Resources.” Paper written for the 8th IASCP Conference, Bloomington, IN, 31 May to 4 June 2000.

Evans, P.T., M. Marschke, and K. Paudyal. 2004. "Flood Forests, Fish and Fishing Villages - Tonle Sap, Cambodia." A Collaborative Study by the Food and Agriculture Organization of the United Nations, Siem Reap and Asia Forest Network.

Evans, T., T. Gray, H. Chamnan, S. Mouyheang, and L. Vanny. 2005. "Farming and its impact on flooded grasslands around the Tonle Sap Lake - A survey in the Kruos Kraom area of Kompong Thom.” Wildlife Conservation Society Cambodia Program, Phnom Penh, Cambodia.

Farmer, P. 1997. "On suffering and structural violence: A view from below," in A. 
Kleinman, V. Das, and M. Lock, eds. Social Suffering. London: University of California Press.

Fox, C. and C. Sneddon. 2004. "Flood Pulses, International Watercourse Law, and Common Property Resources: a Case Study of the Mekong Lowlands." Research Paper No. 2005/20, United Nations University / World Institute for Development Economics Research (WIDER), Helsinki.

Galtung, J. 1969. "Violence, Peace, and Peace Research." Journal of Peace Research, Vol. 6, No. 3, pp. 167-191.

Haftendorn, H. 2000. "Water and International Cconflict." Third World Quarterly, Vol. 21, No. 1, pp. 51-68.

Hap, N., L. Seng, and R. Chuenpagdee. 2006. "Socioeconomics and Livelihood Values of Tonle Sap Lake Fisheries." Inland Fisheries Research and Development Institute, Phnom Penh, Cambodia.

Keskinen, M., K. Mehtonen, and O. Varis. 2007. "Transboundary cooperation vs. Internal Ambitions - the role of China and Cambodia in the Mekong Region," in Jansky, Libor, Nakayama, Mikiyasu, and Pachova Nevelina, eds. Endangered International Waters: Lessons from Domestic Security Issues. Tokyo: United Nations University Press. In press.

Keskinen, M. 2003. Socio-Economic Survey of the Tonle Sap Lake, Cambodia. Master's Thesis. W ater Resources Laboratory. Helsinki University of Technology, Espoo. Available at http://users.tkk.fi/u/mkeskine/dippa.pdf.

Keskinen, M. 2006. "The Lake with Floating Villages: Socioeconomic Analysis of the Tonle Sap Lake." International Journal of Water Resources Development, Vol. 22, No. 3, pp. 463-480.

Kummu, M. and D. Lamberts. 2007. "Tonle Sap Flooded Forest in Threat: Impacts of Mekong Upstream Development on Natural Water Levels." Draft paper for Mekong@ Crossroads Workshop, 14-15 May 2007, Chiang Mai.

Kummu, M. 2007. Personal communication. Helsinki University of Technology, Espoo, 26 February 2007

Kurien, J., N. So, and S.O. Mao. 2006. "Cambodia's Aquarian Reforms: The Emerging Challenges for Policy and Research." Inland Fisheries Research and Development Institute, Phnom Penh, Cambodia.

Lamberts, D. 2006. "The Tonle Sap Lake as a Productive Ecosystem." International Journal of Water Resources Development, Vol. 22, No. 3, pp. 481-495.

Le Billon, P. 2000. "The Political Ecology of Transition in Cambodia 1989-1999: War, Peace and Forest Exploitation.” Development and Change, Vol. 31, pp. 785 805.

Le Billon, P. 2007. "The Politics of Forest Exploitation in Cambodia," in B. Kiernan and C. Hughes, eds. Conflict and Change in Cambodia. New York: Routledge.

McKenney, B. and P. Tola. 2002. "Natural resources and rural livelihoods in Cambodia: A baseline assessment." Working Paper 23, Cambodia Development Resource Institute, Phnom Penh.
Middleton, C. and P. Tola. 2007. "Do community organisations exist for managing water resources around Tonle Sap Lake?" in The Modern Myths of the Mekong forthcoming.

Molle, F. 2005. "Irrigation and water policies in the Mekong region: Current discourses and practices." Research Report 95, IWMI, Colombo, Sri Lanka.

NGO Forum. 2000. "Fishing Conflict in Battambang." Electronic report of the NGO Forum on Cambodia. Available at http://www.ngoforum.org.kh/Environment/ Docs/Fishing_Conflict_in_Battambang.htm.

NIS. 2004. Cambodia Inter-Censal Population Survey 2004 - General Report, National Institute of Statistics, Ministry of Planning, Phnom Penh.

Ohlsson, L. 1999. "Environment, Scarcity, and Conflict - A Study of Malthusian Concerns." PhD dissertation, Department of Peace and Development Research, University of Göteborg.

Öjendal, J. and K. Sedara. 2006. "Korob, Kaud, Klach: In Search of Agency in Rural Cambodia." Journal of Southeast Asian Studies, Vol., Issue 3, pp. 507-526.

Ostrom, E. 1990. Governing the Commons: The Evolution of Institutions for Collective Action. New York: Cambridge University Press.

Peluso, N.L. and Watts, M., eds. 2001. Violent Environments. Ithaca, NY: Cornell University Press.

People's Daily Online. 2005. "Cambodian PM dismisses impact of Mekong's upstream dams.” Xinhua, 30 June 2005.

Postel, S.L. and A.T. Wolf. 2001. "Dehydrating Conflict." Foreign Policy, Issue 126 (September-October), pp. 60-67.

Pryor, F.L. 2007. "Water Stress and Water Wars." The Economics of Peace and Security Journal, Vol. 2, No. 2 (this issue).

Ratner, B.D. 2006. "Community Management by Decree? Lessons From Cambodia's Fisheries Reform." Policy Review, Society and Natural Resources, Vol. 19, pp. 79-86.

Ratner, B.D., D.T. Ha, M. Kosal, A. Nissapa, and S. Chanphengxay. 2004 Undervalued and Overlooked: Sustaining Rural Livelihoods through better Governance of Wetlands. WorldFish Center Studies and Reviews, 28.

Resurreccion, B.P. 2006. "Rules, Roles and Rights: Gender, Participation and Community Fisheries Management in Cambodia's Tonle Sap Region." International Journal of Water Resources Development, Vol. 22, No. 3, pp. 433-447.

Salayo, N.D., M. Ahmed, L. Garces, and K. Viswanathan. 2006. "An Overview of Fisheries Conflicts in South and Southeast Asia: Recommendations, Challenges and Directions." NAGA. WorldFish Center Quarterly, Vol. 29, Nos. 1/2, pp. 11 20.

Scott, J.C. 1998. Seeing Like a State: How Certain Schemes to Improve the Human Condition Have Failed. New Haven, CT: Yale University Press.

Shiva, V. 2002. Water Wars: Privatization, Pollution, and Profit. Boston, MA: South 
End Press.

Sina, L. 2003. "Cambodia Fisheries Conflicts in the Post War Era and the Creation of Fishing Communities: A case of fishing lot conflicts around Tonle Sap River and the Great Lake." Journal of Regional Fisheries, Vol. 43, No. 2, pp. 89-106.

Sithirith, M. and C. Grundy-Warr. 2007. "Spaces of Engagement and Contested Territories of the Tonle Sap.” Draft Paper prepared for the RCSD Conference in Chiang Mai, 27-29 January 2007.

Steins, N.A. and V.M. Edwards. 1999. "Collective Action in Common-Pool Resource Mangament: The Contribution of Social Constructivist Perspective to Existing Theory." Society \& Natural Resources, Vol. 12, pp. 539-557.

Tam, C.-L. 2006. "Harmony Hurts: Participation and Silent Conflict at an Indonesian Fish Pond." Environmental Management, Vol. 36, No. 1, pp. 1-15.

Tarr, C.M. 2003. "Fishing lots and people in Cambodia," in M. Kaosa-ard and J. Dore, eds. Social Challenges for the Mekong Region. Bangkok: White Lotus.

Upreti, B.R. 2001. "Conflict Management in Natural Resources - A Study of Land, Water and Forest Conflicts in Nepal." PhD Thesis, Wageningen University.

Watkins, K. and A. Berntell. 2006. "How to avoid war over water." International Herald Tribune. 24 August 2006.

World Bank. 2006a. "Cambodia at a glance." Available at http://devdata.worldbank.org/AAG/khm_aag.pdf.

World Bank. 2006b. "Cambodia - Halving Poverty by 2015? Poverty Assessment 2006." Report No. 35213-KH. W ashington, DC: World Bank.

World Bank. 2004. "Cambodia at the Crossroads: Strengthening Accountability to Reduce Poverty.” Report No. 30636-KH. Washington, DC: Word Bank. 